\title{
LONG VOWELS IN PROTO-JAPANESE
}

\begin{abstract}
The goal of this article is to provide internal and partial external evidence that Proto-Japanese had both vowel length and pitch accent. The author examines the evidence from Ryukyuan dialects of Japanese and from prehistoric Japanese loanwords in the Ainu language. This combined evidence demonstrates that the majority of Pre-Proto-Japanese words with initial vowel length may be associated with an initial low pitch. However, there are also certain words which combine initial high pitch and initial vowel length. Comparative data from Tungusic and Korean are also used.
\end{abstract}

The goal of this article is to provide internal and partial external evidence for the reconstruction of long vowels in Proto-Japanese (PJ). ${ }^{1}$ It is widely accepted de facto that the oldest variety of Japanese, attested by texts of the Nara period (712-794 AD), does not demonstrate the difference between long and short vowels, and that most long vowels in different modern Japanese dialects represent the result of a later development, mostly due to loss of intervocalic consonants with the following monophtongization of two vowels: $\mathrm{cv}_{1} \mathrm{cv}_{2}>\mathrm{cv}_{1} \mathrm{v}_{2}>\mathrm{cv}$.

There are two attempts to reconstruct long vowels for $\mathrm{PJ}$, one by Hattori Shiro (1978-79), the other by Samuel E. Martin (1987). Hattori proposed the reconstruction of long vowels in some words belonging to $\mathrm{PJ}$ accent classes 2.3, 2.4, 2.5 and also in a couple of words from PJ accent classes 2.1 and 2.2 on the basis of correspondence between primary long vowels $^{2}$ in Shuri and Onna dialects, both located on Okinawa island (Hattori $(1979,21-22)$ ). However, he cites many words with inconsistent reflexes, e.g., Shuri haai 'needle' versus Onna p'ai 'needle' (Hattori (1979, $21,104)$ ) or Shuri numi 'chisel' versus Onna nuumii 'chisel' (Hattori $(1979,21,105))$.

Martin's proposal is far more consistent and logical. He eliminates the pitch distinction from $\mathrm{PJ}$ and proposes to reconstruct $\mathrm{PJ}$ long vowels in place of the first low-pitched mora in accent classes 2.3 and 2.4 as well as for both first and second moras in accent class 2.5 (Martin $(1987,250-$ 252)). If none of the Japanese dialects really preserves PJ long vowels, then this approach seems the only possible one since it provides a rational explanation for the origin of pitch accent in Japanese. Martin explains long vowels in Shuri and Onna as a result of sporadic lengthening (Martin $(1987,253))$. In many cases, especially when words with long vowels in 
Shuri and Onna do not coincide, it seems to be a reasonable explanation. However, one problem remains: how does one explain the cases when Shuri and Onna both exhibit long vowels in the same words? If it is possible to compile a list of such words longer than, say, four or five words, then the probability of simultaneous sporadic lengthening in two dialects will be quite low. This probability will be even lower if it is possible to extend such a list to include other dialects. The best results certainly would be obtained if there were some dialects outside Ryukyu that have long vowels in the same words.

I suggest that the four Ryukyuan dialects Shuri, Omu [oomu], Nakijin, and Onna ${ }^{3}$ preserved Proto-Okinawan (PO) vowel length in the first syllable of the words included in the following chart. It seems that there is no supporting evidence from dialects outside Ryukyu. Some of these words also have long vowels in other Ryukyuan dialects, most frequently in the Ora [oora] dialect of Miyakojima, but their reflexes are not consistent; and in order to maintain the strictness of the comparative method, I do not include these data. Since we already have four dialects it is natural to assume that vowel length does not result from sporadic lengthening, and that it must go back to the proto-language. However, it is methodologically difficult, though not impossible, to claim that these PO long vowels go back to Proto-Ryukyuan or Proto-Japanese, because there may be cases when only one group of a language family preserved some feature lost in other groups. It is necesary to note that the data on Omu and, especially, on Onna dialects which are at my disposal are quite scarce. In most cases I tried to include data from at least three dialects. Moreover, there are also many words with long vowels in Shuri and/or Nakijin, but their counterparts in other sources are lacking. I am planning to do field work in order to fill in these gaps, so the list of fourteen words shown in Table I should be considered a preliminary one.

There is also another source which, I believe, provides evidence for PJ long vowels. There are PJ loanwords in Proto-Ainu (PA) with long vowels. I will discuss this evidence later.

\section{COMMENTARIES TO RECONSTRUCTIONS}

1. PO * paatu B 'pigeon'. OJ patwo (Igarashi $(1969,115)$ ). I propose PJ *paatwo 3.4 instead of PJ *patwo 2.3 'pigeon' (Martin $(1987,402)$ ). Cf. well-known MK pitwuli LLH 'pigeon' $\left({ }^{1} \mathrm{Yu}(1964,411)\right)$, Seoul pitwulki 'pigeon' (Martin $(1967,851)$ ), Kyengpuk pidilgipidulgi, Kyengnam pidalkhi, Cennam pida:lgipidu:lgi 'pigeon' (Choy $(1978,887)$ ) < PK *pitVl=i LLH 'pigeon'. Notice that PK word has a low-pitched first syllable. 
TABLE J

\begin{tabular}{|c|c|c|c|c|c|}
\hline gloss & Shuri & Omu & Nakijin & Onna & Proto-Okinawan \\
\hline 'pigeon' & hooto B & hooto $B$ & p'ootuu' B & $?$ & ${ }^{*}$ paatu B \\
\hline 'mold' & kaabui B & $?$ & haabui A & $?$ & *kaabui A \\
\hline "shadow' & kaagaa B & kaagi B & k'aagaa A & k'aagi B & *kaagai B \\
\hline 'bet' & kaakii B & $?$ & k'aakii A & $?$ & *kaakii B \\
\hline 'tortoise' & kaamii B & kaamii B & haamii $B$ & $?$ & *kaamii B \\
\hline ‘spider' & kuubaa B & koobu $=\mathrm{B}$ & hubu $\mathrm{C}$ & k'uubaa B & ${ }^{*}$ kuubu $/{ }^{*}$ koobu $\mathrm{C}$ \\
\hline 'carp' & kuurijuu B & $?$ & kuurjuu B & $?$ & ${ }^{*}$ kuurjuu B \\
\hline 'hard red soil' & niibi B & $?$ & niibi ${ }^{2} B$ & $?$ & *niibi B \\
\hline 'rainbow' & nuuzi A & noozi A & t'iNtoo-nooziri C & $?$ & ${ }^{*}$ nuuzi A \\
\hline 'monkey' & saaruu B & saaru B & saaruu C & saaru B & *saaru C \\
\hline "heron' & saazi A & $?$ & saazai A & $?$ & ${ }^{*}$ saazi A \\
\hline 'girdle' & Puubi B & Puubi B & hicuubi B & $?$ & *?uubi B \\
\hline 'mortar' & r̉uusi B & & Pusi C & Puusu B & *ipuusu C \\
\hline 'axe' & uuN B & uuN B & uunuu B & $?$ & $*_{\text {wuunu B }}$ \\
\hline
\end{tabular}

Aspiration in Nakijin and Onna is rendered by a sign ['] after a consonant,

2 Nakijin: "sandstone".

2. $\mathrm{PO}{ }^{*}$ kaabui A (accent class B in Shuri is irregular) 'mold'. OJ kabiy (Ono $(1974,319)$ ). I propose PJ ${ }^{*} k a a n p / u / o f=C i 3.1$ instead of PJ ${ }^{*} k a n p[u / o]=C i 2.1$ (Martin $(1987,431)$ ). Martin suggests the possibility that the word may be from the verb infinitive 'sprout' (Martin (1987, 431)). However, OJ kabyi 'sprout', though it belongs to the same accent class, shows a different vowel in the second syllable. Taking into consideration this plus the semantic difference, it is safer to assume that 'sprout' and 'mold' are not related. Moreover, we have MK kwomphuy= RL 'to become moldy', Early Modern Korean kwom 'mold' ( ${ }^{1} \mathrm{Yu}(1964$, 72)), kwomphuy= LH (Nam (1960, 52)), Seoul kwo:mphangi 'mold' (Martin $(1967,162)$ ), Kyengnam koompheni, Kyengpuk komsagu 'mold' (Choy $(1978,476))$. The accentual data from 'Yu (1964) and Nam (1960) are conflicting, but a long vowel in Seoul and Kyengnam supports the accentuation given in ${ }^{1} \mathrm{Yu}$ (1964). Thus it is possible to reconstruct PK *kwomV LH 'mold' and compare it with PJ *kaanp $[u$ /ol = 'mold' (Martin $(1966,236))$. Consequently, we have no need to connect 'mold' and 'sprout' in Japanese. Notice that PK word has a low-pitched first syllable.

3. PO *kaagai B ? < C 'shadow'. OJ kagey 'shade', 'shadow' (Igarashi $(1969,41))$. Martin reconstructs PJ ${ }^{*} k a n k a=C i 2.5$ and proposes also that ${ }^{*} k a n k a=C i<{ }^{*} k a n$ ni] $k a$ (Martin $(1987,432)$ ). It seems that ${ }^{*} k a n[i]$ $k a$ is quite tentative and is not supported by any crucial internal evidence. I suggest $\mathrm{PJ}{ }^{*} k a a n k a=C i 3.7$ 'shade', 'shadow'. 
4. $\mathrm{PO}{ }^{*}$ kaakii $\mathrm{B}$ (Nakijin has irregular accent A) 'bet'. In the meaning 'to bet' it is attested only in MJ kake= (lower bigrade conjugation) < *kakey $=($ Ono $(1974,282))$. The word is listed in Martin (1987) within the entry for 'hang it' (Martin $(1987,702)$ ). I am doubtful about this semantic unification of 'hang it' and 'bet' and suggest $\mathrm{PJ}{ }^{*} k a k a=\mathrm{Ci} 2.3<$ * $k a a k a=C i 3.4$ 'bet' (T kake 2, K 2, KA B; Hirayama $(1989 / 1960,123)$ ).

5. PO *kaamii B 'tortoise'. OJ kamey 'tortoise' (Igarashi $(1969,47)$ ). Martin reconstructs PJ *kamaCi 2.3 (Martin $(1987,435)$ ). I suggest PJ *kaama $=\mathrm{Ci}$ 3.4. Cf. MK kepwup LH 'tortoise' (Martin $(1966,244)$ ). Notice that PK word has a low-pitched first syllable.

6. PO ${ }^{*} k u u b u /{ }^{*} k o o b u$ C 'spider'. Nakijin hubu has a short vowel. Nevertheless, the other three dialects exhibit a long one, and external evidence also points to a long vowel (see below). There is a parallel Shuri form $k u b u$ B 'spider' with a short vowel, but it belongs to the written language (OGJ (1963, 324, 344), Ahagon (1983, 172)). OJ kumo 'spider' (Igarashi $(1969,54))$. Martin $(1987,463)$ reconstructs PJ ?*kunpo < ?*konpo 2.5. I suggest $\mathrm{PJ}$ *kuumpo $<$ ?*koompo 3.7.

7. PO *kuu’juu B ? < C 'carp'. OJ kwopyi 'carp' (Ono $(1974,511)$ ). Marin $(1987,454)$ reconstructs PJ *kwopi 2.5 . Since there is kô-rui [wo] in the OJ word, a long vowel in PO may seem secondary, and it probably corresponds to $\mathrm{PJ} * a C u$ or ${ }^{*} u C a$. Internal reconstruction can add nothing more in this case. I suggest $\mathrm{PJ}{ }^{*} k a a C u=p i 3.7$ 'carp' on the basis of external evidence (see below).

8. PO *niibi B 'hard red earth'. OJ ni 'earth' (Igarashi $(1969,107)$ ). Martin $(1987,496)$ reconstructs PJ * ni ?1.3b 'earth', 'dirt', 'red clay', 'red', 'beautiful'. The correspondence between OJ $[\varnothing]$ and Okinawan $[-b-]$ is strange. There is a possibility that the Okinawan word is a compound with an unclear second component. However, there is no evidence to support this. I suggest PJ *niiCi 3.4 'earth', 'red', 'red clay'.

9. $\mathrm{PO}{ }^{*} n o o z i{ }^{*}$ nuuzi A 'rainbow'. OJ evidence is only from EOJ nozi 'rainbow' (M 3414), thus there is no basis to decide whether we have OJ "nwozi or *nozi. MJ nizi 'rainbow' (Ono (1974, 981)). Martin (1987, 498-499) reconstructs PJ ?*ni(i)nsi ?2.2a $<93.3$ 'rainbow'. I believe that EOJ and Ryukyuan provide evidence for PJ non-front vowel in the first syllable and suggest $\mathrm{PJ}$ *noonsi 3.3. 'rainbow'. While EOJ / $\mathrm{u} /$ occurs as a reflex of OJ $i y<{ }^{*} u C i$ (e.g. EOJ $t u k u,{ }^{4}$ OJ tukiy 'moon'), there is not much evidence that EOJ /o/ occurs as a reflex of $\mathrm{PJ}{ }^{*} \underline{o} C i$. Moreover, Okinawan $[\mathrm{u}]$ or $[\mathrm{o}]$ is not a regular reflex for $\mathrm{PJ} * u C i$ or $* \underline{o} C i$. Thus it seems unlikely that the word in question might have a trisyllabic source *noCinsi or *nuCinsi. MJ and T nizi may be accounted for by regressive vowel assimilation. Whitman $(1985,34)$ proposed that all OJ syllables $n i$ 
and $t i$ contain otsu-rui vowels, and, thus, go back to *niy and *tiy. I do not intend to discuss this problem in detail here since it is not my topic, but I would like to state that in general I disagree with his theory. Internal evidence cited by Whitman shows that in several cases OJ $t i<t i y$ and $n i$ $<$ niy, but this can be expected within the boundaries of the traditional theory according to which pre-OJ ${ }^{*} t y i$ and ${ }^{*} t i y,{ }^{*}$ nyi and ${ }^{*}$ niy merged into $\mathrm{OJ} t i$ and $n i$ respectively. The internal evidence that pre-OJ ${ }^{*} t y i>$ OJ $s i$ and pre-OJ ${ }^{*} n y i>{ }^{*} y i>\mathrm{OJ} i$, crucial for the proof of this hypothesis, is very weak and largely speculative. It seems also that Whitman did not provide MK etymologies for OJ si < tyi and $i<* n y i$. On the other hand, there is certain evidence from Altaic languages in favor of the traditional explanation of $i y$ and $y i$ merging after coronals. I will provide several examples supporting OJ $t i<{ }^{*} t y i$ and $n i<{ }^{*} n y i$ : PAL ${ }^{*} t^{h} i$ 'blood' > WM cisun 'blood' < PM *ti=sun, OJ $t i$ 'blood' < PJ * $t i 1.1$ (Martin $(1987,545)$ ); PAL *djaka- 'be close' > PT *yak= 'be close', PJ *tika = B 'be close' (Martin $(1987,842)$ ); PAL *nim/al= 'to boil' > PMT ${ }^{*}$ nim $=$ 'to boil' (SSTM $(1975,593)$ ), PJ *niCa= A 'to boil' (Martin $(1987,736))$; PAL *nilrll $k i=>$ PMT *nilrll $k i=$ 'to make noise' (SSTM (1975, 599)), PJ *nigyi-yaka < *ni(n)ki-da-ka 4.11 'lively', 'bustling' (Martin $(1987,496))$.

10. PO *saaru C 'monkey'. MJ saru LH "monkey' (Ono $(1974,578))$. Martin reconstructs PJ *saru 2.5 'monkey'. I suggest PJ *saaru 3.7 'monkey'.

11. PO *saazi A 'heron'. MJ sagi 'heron' (Ono $(1974,545))$. Martin $(1987,515)$ reconstructs $?^{*}$ sagyi < * sanki 2.1 'heron' on the basis of Shuri palatalization. I suggest PJ *saanki 3.1. Cf. MK say R 'bird' (Martin $(1966,226))<\mathrm{PK} * \mathrm{saC} i \mathrm{LH}$, though the semantics and correspondences between $\mathrm{PJ}{ }^{*}$-nk- and $\mathrm{PK} *-C$ - may be problematic. Notice that PK word has a low-pitched first syllable.

12. PO *'́uubi B ? < C 'girdle'. OJ myi=obyi 'girdle' (Igarashi (1969, 133)). Martin $(1987,503)$ reconstructs $\mathrm{PJ}$ *onp/a-C/i 2.4 'girdle'. I suggest $\mathrm{PJ}{ }^{*}$ oonpl $=C / i^{5} 3.5$ 'girdle'.

13. PO *'iuusu C 'mortar'. Though Nakijin has rusi with a short vowel, I still decided to include this word in the list, mainly on the basis of Ainu evidence cited below. OJ usu 'mortar' (Igarashi $(1969,25))$. Martin (1987, 564) reconstructs. PJ *usu 2.4 'mortar'. PA has *niisu HLL 'mortar' (Vovin 1992 fothcoming), which I believe comes from PA *nii 'tree' + *uusu 'mortar' (< $\mathrm{PJ}{ }^{*} u u s u$ ). If the PA form of this compound were ${ }^{*} n i i=u s u$ or ${ }^{*} n i=u s u$, we would now have in Hokkaidô dialects the form *niwsu HL instead of nisu HL, and in Sakhalin dialects *niwsu instead of niisu. I suggest PJ * uusu 3.5 'mortar'. 
14. PO * wuиnu B 'axe'. Ono $(1974,2421)$ cites OJ wono, but gives an example from $M$ 3232, where this word is written ideographically. Thus there is no evidence showing whether this word in OJ was wono or wonwo. Martin $(1987,507)$ reconstructs $\mathrm{PJ}$ *bono 2.3 . He supposes also that this word may be a compound < *bo- 'small' $+{ }^{*} n a$ 'blade'. However, there is not enough evidence for hypothetical PJ *na 'blade' (reconstructed on the basis of -na in katana 'small sword', 'knife' and kana 'plane' by Martin $(1987,490))$. Moreover, the nature of the second vowel in OJ wono is unclear: it may go back to wo $<{ }^{*} u C a$. I suggest PJ *boonlo/wol 3.4 'axe'.

There are only fourteen words in the above list. I can also add four words where vowel length is testified by PJ loanwords in PA: ${ }^{6}$

1. PA *kaani HHH 'metal' (Vovin (1992) forthcoming, 137)). Martin $(1987,437)$ reconstructs $\mathrm{PJ} *$ kana $=C i 2.1$ 'metal'. I suggest $\mathrm{PJ}{ }^{*} k a a n a=C i$ 3.1 'metal'.

2. PA *paakari HLLL 'to measure', 'to weigh' (Vovin (1992) forthcoming, 171)). Martin $(1987,683)$ reconstructs $\mathrm{PJ} *$ paka $2.3=r a=$ 'to measure', to calculate'. I suggest PJ *paaka $3.4=r a=$ 'to measure', 'to weigh'.

3. PA *tuuki HLL 'sake cup' (Vovin (1992 forthcoming, 207)). Martin $(1987,554)$ reconstructs $\mathrm{PJ}$ *tuki $2.2 \mathrm{~b}$ 'cup'. I suggest $\mathrm{PJ}$ *tuuki 3.3 'cup'.

4. PA *tuuti LLH 'large wooden hammer' (Vovin (1992 forthcoming, 208)). Martin $(1987,557)$ reconstructs $\left.\mathrm{PJ}{ }^{*} t u t i l y\right]<{ }^{*} t u t u=C i \quad 2.4 ?<$ 3.5 'hammer'. I suggest PJ *tuutu $=\mathrm{Ci} 3.5$ 'hammer'. The Ainu word is probably a loanword from early EOJ, which as we know lost the contrast between $k \hat{o}$ - and otsu-rui vowels before eighth century.

Following Hattori (1967) I reconstruct PA vowel length according to the Sakhalin Ainu data, since it is not preserved in any Hokkaido dialects. The distinctive vowel length for PA can be reconstructed only in first syllables. ${ }^{7}$ In several cases the reconstruction of vowel length is also supported by Kuril Ainu data, which preserve it occasionally (Vovin (1992 forthcoming)).

One can doubt whether PJ loanwords in PA would preserve original vowel length. However, the examples above also show that PA accent of these loanwords coincides with $\mathrm{PJ}$ accent as reconstructed in Martin (1987). It would be a linguistic miracle if both vowel length and pitch accent in PJ loanwords in PA happened to be the same as in PJ due to simple coincidence.

We get the following distribution of these words by PJ accent classes:

$\begin{array}{cccccc} & 3.1 & 3.3 & 3.4 & 3.5 & 3.7 \\ \text { total: } 18 & 3 & 2 & 5 & 3 & 5\end{array}$


The combined evidence comprises only eighteen words, which constitutes less than one percent of the PJ vocabulary reconstructed in Martin (1987). This fact obviously endangers the proposed reconstructions of words with long vowels. However, I prefer to propose the following solution. There are cases when it is impossible to solve a problem exclusively by means of internal reconstruction. I believe that Martin is right in a broad sense: the majority of pre-PJ long vowels are probably hidden under low-pitched syllables. Meanwhile, Hattori is right in a narrow sense: there is internal evidence allowing us, in a limited number of cases, to reconstruct long vowels without reference to pitch distinctions. Thirteen of the proposed reconstructions with long vowels are in low register (accent classes 3.4, 3.5, and 3.7). Low pitch is certainly a good phonetic condition for vowel length to be preserved. However, five of the reconstructions with long vowels are in high register (accent classes 3.1 and 3.3). I believe that it is not necessary to eliminate pitch distinctions in PJ. It may have had pitch distinctions as well as vowel length, since one does not necessarily preclude the other. I would say that PJ lost most of its long vowels; at least, internal reconstruction provides evidence only for a few of them. If we look for pre-PJ long vowels, the majority of them are probably hidden in words belonging to PJ low register accent classes. However, some long vowels, as the above evidence shows, might also be hidden in $\mathrm{PJ}$ high register accent classes.

In order to support my reconstructions, I provide below additional external evidence for two of the reconstructed words with long vowels, based on comparisons with Proto-Manchu-Tungus, where it is also possible to reconstruct long vowels (Tsintsius (1949, 95-109)). This is a different kind of external evidence from previously cited Ainu data, since it relies not on loanwords but on data from genetically related Altaic languages. ${ }^{8}$

PJ *kuumpo/*koompo 3.7 'spider'. Cf. PMT ${ }^{*} k æ x m / p / V$ 'water spider'; Ewenki keem=kaan 'crayfish', Ewen qææm=qaar 'water spider,', Oroch kææpi 'tick' (SSTM $(1975,388))$. Notice that the well-known parallel to this Japanese word, MK kemuy LH 'spider' ('Yu $(1964,41))$, has a low-pitched first syllable.

$\mathrm{PJ} * k$ wopi $2.5<{ }^{*} k a a C u=p i 3.7$ 'carp'. I suggest PJ *kaaCu=pi 3.7 exclusively on the basis of external comparison with PMT *xaangu 'crucian carp'; Neghidal xangu, Oroch xaangu, Ulchi xangu, Nanai xango (SSTM $(1975,462))$, because internal reconstruction is unable to show further progress here. Proto-Altaic (PAL) $* l g l$ is preserved in PMT, but not in PJ: PAL *bango 'main', 'foremost', 'prominent' > PMT *bongo 'first', 'main', 'foremost', 'forward' (SSTM $(1975,94))$, PJ * pwo 'prominent one/thing' (Martin $(1987,402)$ ) < *paCu; PAL *tugna 'horn' > PMT 
(Ewen) $)^{10}$ *tagña 'horn' (SSTM (1977, 163)), PJ *tunwo 'horn' (Martin $(1987,556))<*$ tuna $=\mathrm{Cu}$; PAL * inV 'dog' > PMT * ina- 'dog' (SSTM $(1975,661))$, PJ *inu 'dog' (Martin $(1987,425))$.

Japanese-Korean comparative evidence may be combined with JapaneseTungusic comparative evidence in Table II:

TABLE II

\begin{tabular}{|c|c|c|c|}
\hline & PJ & PK & PMT \\
\hline 'pigeon' & *paatwo 3.4 & $*_{\text {pit }} \mathrm{VI}=\mathrm{LL}$ & - \\
\hline 'mold' & $* \operatorname{kaanp}[\mathrm{u} / \mathrm{o}]=3.1$ & ${ }^{*}$ kwomV LH & - \\
\hline 'tortoise' & $*$ kaama $=3.4$ & *kepwup LH & - \\
\hline 'spider' & *koompo 3.7 & ${ }^{*}$ kemu $=$ LH & $*_{\text {kææm }|\mathrm{p}| \mathrm{i}}$ \\
\hline 'carp' & ${ }^{*} \mathrm{kaaCu}=$ pi 3.7 & - & *xaangu \\
\hline 'heron' & *saanki 3.1 & *saCi LH 'bird' & - \\
\hline
\end{tabular}

I would like to make the following hypothetical conclusions on the basis of this chart:

1) There is a probable correspondence between long vowels in PJ and PMT. However, before more Ryukyuan data are obtained it is difficult to find further evidence to allow more PO reconstructions with long vowels.

2) It seems that vowel length, but not the L pitch in PJ, corresponds to $\mathrm{L}$ pitch in PK, since we have two PJ words belonging to class 3.1. I believe that this possibility deserves further investigation.

3) It is easy to notice that the vowel correspondences in the chart above are far from ideal, with the exception of the last two examples. Is it possible that vowel length in these cases is due to some mysterious "laryngeals"? Or should we have to reconstruct diphthongs?

All these are questions to be answered by future research.

\section{NOTES}

1 The following abbreviations are used in this article:

$\begin{array}{ll}\text { A } & \text { Tonic accent in Shuri, all-high in Nakijin } \\ \text { B } & \text { Atonic accent in Shuri, low-high in Nakijin } \\ \text { C } & \text { High-low accent in Nakijin } \\ \text { EOJ } & \text { Eastern Old Japanese } \\ \text { H } & \text { High pitch } \\ \text { K } & \text { Kyôto dialect } \\ \text { KA } & \text { Kagoshima dialect }\end{array}$




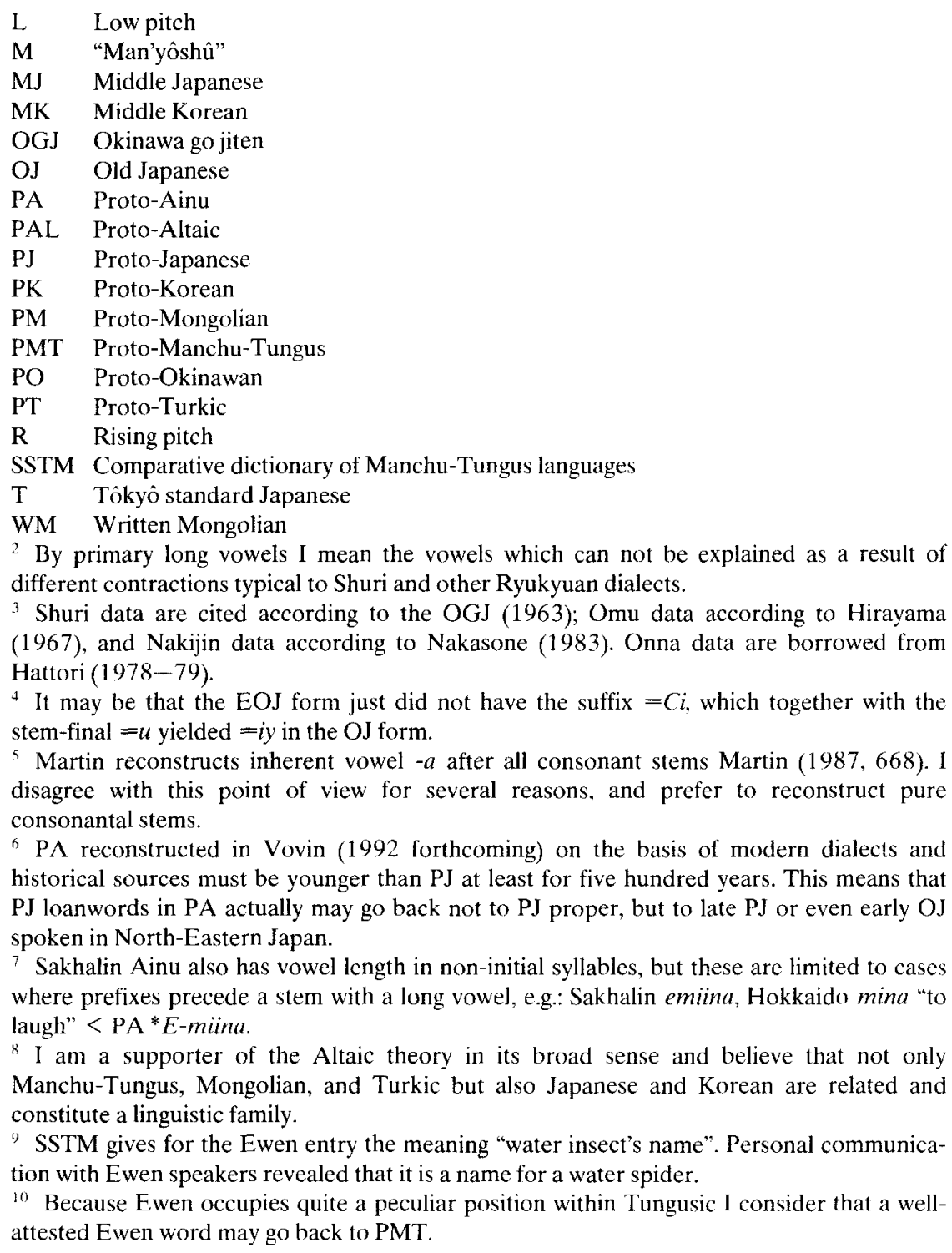

\section{REFERENCES}

Ahagon, Chôshô (1983) Ryûka kogo jiten [A Dictionary of Old Language of Ryukyuan Songs], Naha shuppansha, Naha.

Choy, Hakkun (1978) Hankwuk pangen sacen [A Dictionary of Korean Dialects], Hyenmunsa, Seoul.

Hattori, Shirô (1967) "Ainu go no on'in kôzô to akusento [Phonological Structure and Accent of Ainu|," Onsei Kenkyû 13, 207-223. 
Hattori, Shirô (1978-79) "Nihon sogo ni tsuite [About Proto-Japanese]," 1-22. Gengo.

Hirayama, Teruo (1967) Ryûkyû Sakishima hôgen no sôgôteki kenkyû |A Comprehensive Study of Southern Ryukyuan Dialects], Meiji Shoin, Tôkyô.

Hirayama, Teuro (1989/1960) Zenkoku akusento jiten [A Dictionary of Pitch Accents in All Dialects], Tôkyôtô shuppan, Tôkyô.

Igarashi, Jin'ichi (1969) Jôdai kanazukai jiten [A Dictionary of Old Japanese Spelling], Shôgakkan, Tôkyô.

${ }^{1} \mathrm{Yu}$, Changton (1964) Ico e sacen [A Dictionary of the Korean Language During Li Dynasty Period, Yensey tayhakkyo chwulphanpu, Seoul.

Martin, Samuel Elmo (1966) "Lexical Evidence Relating Korean to Japanese," Language $42,185-251$.

Martin, Samuel Elmo, Lee, Yang-ha, Chang, Sung-un (1967) A Korean-English Dictionary, Yale University Press, New Haven and London.

Martin, Samuel Elmo (1987) The Japanese Language through Time, Yale University Press, New Haven and London.

Nakasone, Seizen (1983) Okinawa Nakijin hogen jiten |A Dictionary of the Nakijin Dialect on Okinawa], Kadokawa, Tôkyô.

Nam, Kwangwu (1960) Ko e sacen [A Dictionary of the Middle Korean Language], Thap chwulphansa, Seoul.

OGJ (1963) Okinawa go jiten [A Dictionary of the Okinawan Language], Okurashô insatsukyoku, Tôkyô.

Ono, Susumu (1974) Kogo jiten [A Dictionary of Classical Japanese], Iwanami, Tôkyô.

SSTM (1975) Sravnitel'nyi slovar' tunguso-manchzhurskikh iazykov, tom I [A Comparative Dictionary of the Manchu-Tungus Languages, Vol. 1], Nauka, Leningrad.

SSTM (1977) Sravnitel'nyi slovar' tunguso-manchzhurskikh iazykov. tom II [A Comparative Dictionary of the Manchu-Tungus Languages, Vol. 1], Nauka, Leningrad.

Tsintsius, Vera (1949) Sravnitel'naia fonetika tunguso-man'chzhurskikh iazykov [A Comparative Phonetics of the Manchu-Tungus Languages], Uchpedgiz, Leningrad.

Vovin, Alexander (1992 forthcoming) A Reconstruction of Proto-Ainu, ms., to be published by E. J. Brill, Leiden.

Whitman, John Bradford (1985) The Phonological Basis For the Comparison of Japanese and Korean, PhD dissertation, Harvard.

Received 26 December 1991

Revised 2 June 1992

University of Michigan

Department of Asian Languages and Cultures

3070 Frieze Building, Ann Arbor, MI 48109-1285

E-mail: alexander.vovin@um.cc.umich.edu 